\title{
Çocuk Edebiyatı Bağlamında Gülten Dayığlu'nun Fadiş Romanı
}

\author{
Gülten Dayığglu's Novel Fadiş in the Context of Children's Literature
}

\author{
Mehmet Bakır ŞENGÜL*
}

\begin{abstract}
$\ddot{O} z$
Genel edebiyat biliminin bir parçası olarak kabul edilen çocuk edebiyatı, 2-15 yaş grubundaki bireylerin duygu, düşünce ve hayallerini irdeleyen çoğu zaman da zenginleştiren sözlü veya yazılı eserleri kapsar. Çocukların düşünce ve hayallerinin neredeyse sınırsız oluşu, bu alanda yazı kaleme alan yazarların zor bir uğraş ile karşı karşıya olduklarını da gösterir. Masumiyet ile neredeyse eşdeğerde tutulan çocuk kavramını yapıtlarının merkezine alan yazarların, yapıtlarını daha dikkatli ve ciddi bir sorumluluk anlayışıyla kurgulamaları bir zorunluluktur. Yani çocuk edebiyatı, küçük okurlardaki masumiyeti sürdürmek ve geliştirmek odaklı bir tutum ortaya koymayı amaç edinmelidir. Çünkü bu yapıtlar, gerek içerik gerekse yapısal açıdan, çocukların her anlamda sağlıklı bir gelişim göstermelerine doğrudan etki eder ve dolayısıyla bu da çocuk edebiyatına genel edebiyat içerisinde ciddi bir önem atfeder. Bu çalışmada; Türkiye'de çocuk edebiyatının önemli isimlerinden Gülten Dayığlu'nun ilk romanı da olan ve neredeyse yarım yüz yıldır hâlâ okurlarıyla buluşmaya devam Fadiş adlı eseri, çocuk edebiyatı bağlamında incelenmiştir. Roman, hem tematik hem de yapısal bir düzlemde ele alınmıştır. Eserde işlenen konular ve bu konuların küçük okurların dünyasındaki izdüşümleriyle onlardan beklenen tavır ve davranışların yansıtılma biçimleri analitik bir yaklaşımla değerlendirilmiştir. Çalışmada öncelikle çocuk edebiyatının kuramsal çerçevesi ana hatlarıyla ortaya konacaktır. Ardından roman kahramanı Fadiş adlı küçük kızın dramatik hikâyesi üzerinden, yaşanmışlıkların çocuğun psikolojik gelişimi üzerindeki etkisi açığa çıkarılacaktır. Bu psikolojik gelişimde özellikle oyunların, masalların, dini ve milli unsurların ne denli belirleyici ve dönüştürücü etkisi olduğu üzerinde durulacaktır. Ayrıca çocuğa dönük gerek ailenin gerekse çevrenin kullandığ dilin çocuk gelişimi üzerinde ne ölçüde etkili olduğu tartışlacaktır. Zira yetişkinler tarafından fazla önemsenmeyen sıradan tutum, davranış ve söylemler, çocuklar üzerinde olumlu ya da olumsuz kalıcı etkiler bırakabilmektedir.
\end{abstract}

Anahtar Sözcükler: Türk edebiyatı, çocuk edebiyatı, Gülten Dayığlu, Fadiş.

\begin{abstract}
Children's literature that is regarded as part of mainstream literature covers oral or written works that examine and mostly enrich the feelings, thoughts and dreams of the group of individuals aged between 2-15. The fact that children's thoughts and dreams are almost limitless indicates that writers encounter with difficulties when writing these kinds of texts.It is essential for the writers, who place the concept of child that is almost synonymous with innocence to the core of their writings, to fictionalize their works more carefully and with a high sense of responsibility. In other words, the goal of children's literature should be to focus on maintaining and developing innocence in small children. Due to the fact that these works, both in form and in content, have a direct influence on the healthy psychological development of children, children's literature occupies a very important place in mainstream literature. In this study, one of the prominent figures in children's literature in Turkey, Gülten Dayığlu's first and highly acknowledged novel for almost half a century Fadis is analysed.The novel is examined both thematically and structurally.The subjects presented in the novel, their projections on young reader's imagination along with the expected attitudes and behaviours have been evaluated with an analytical approach.First of all, the theoretical framework of children's literature will be outlined.Then, the influence of the experiences on the psychological development of the child will be revealed through the dramatic story of the little girl named Fadiş, the
\end{abstract}

* Dr. Öğr. Üyesi, Bitlis Eren Üniversitesi Fen Edebiyat Fakültesi, Türk Dili ve Edebiyatı Bölümü, mehmettsengul@gmail.com 
protagonist of the novel.The determining and transformative effects of games, stories, religious and national elements on this psychological development process will be dwelt on. Furthermore, since certain ordinary attitudes, behaviours and words that are disregarded by adults may have a positive or negative impact on children, the effect of language used by both the family and the society on the psychological development of the child will also be discussed.

Keywords: Turkish literature, children's literature, Gülten Dayığlu, Fadiş̧.

\section{Giriş}

Çocuklar için genellikle iki yaşına kadar olan dönem bebeklik dönemi kabul edilir. İki yaşından ergenlik dönemine kadar geçen süre çocukluk dönemini oluşturur. Bu yaş aralığı, cinsiyete veya coğrafi faktörlere göre değişebilmektedir. Ancak çocukluk döneminin 2-15 arasındaki bir yaşa denk geldiği söylenebilir. Çocuk edebiyatı kavramı da bu yaş aralığındakilerle ilgili olan edebiyat için kullanılmaktadır.

Edebiyat kaynağını dilden alan, insanların estetik kaygılarının ifadesi olan ve onların duygu ve düşüncelerinin yansıması yerine geçen bir durumsa çocuk edebiyatı da "çocukların büyüme ve gelişmelerine, hayallerine, duygularına, düşüncelerine, yeteneklerine ve zevklerine hitap eden, eğitirken eğlenmelerine katkıda bulunan sözlü ve yazılı verimlerin tamamı"dır (Yalçın ve Aytaş, 2008, s.17). Şirin (1994, s.26), çocuk edebiyatı kavramının genel edebiyat biliminin bir parçası olduğunu belirtir zira "çocuksuluk, edebiyatın ve sanatın doğasında hep vardır; var olmaya da devam edecektir. Enginün (1991) ise küçükler için müstakil bir edebiyat oluşturmanın yanlış olacağını belirtir; zira "sadece çocuğun okuyucu olarak hedef alındığı eserlerin gelip geçici mahiyette kaldığı, sürekli bir tesir gösteremediği görülmektedir" (Enginün, 1991, s.392).

Yetişkinlerin kaleminden çıkan çocuk edebiyatı ürünleri, küçüklerin dünyasına yakın/yatkın olmak durumundadır. Temel amaç, minik ruhlarda yer alan saflık ve masumiyeti besleyip onları sağlıklı bir birey olarak geleceğe taşımak olmalıdır. Sevgi, merhamet, gayret, çalışma, iyilik, eğitim, vatan, aile, arkadaş, akraba sevgisi gibi konular öncelenmelidir. Bu konular, çocukça bir duyarlılık ve üslupla kaleme alınmalıdır. Küçükleri konu alan metinlerin çocukça bir duyarlılıktan çok daha fazlasını gerektirdiği unutulmamalıdır. Zira bu, "öznesi çocuk olan (bir) edebiyatın” (Şirin, 1994, s.22) gereğidir. Bu tür bir edebiyat, daha fazla eğitsel ve bilişsel bir duyarlılık gerektirmektedir. Çünkü "daha çok eğitici ve ahlaki niteliklere sahip bu edebiyat türünün belki de en önemli yönü, çocuğa zevk vermesidir" (Bilkan, 2005, s.7). Bu ürünler, her şeyden önce küçüklerin algı dünyasına hitap edecek bir düzeyde olmak zorundadır. Küçüklerin psikolojisine uygunluğu odağa almalı, algı dünyalarını yansıtmalı, onlar için kontrollü bir gelişimi öncelemelidir. Felsefi analizler, ideolojik tartışmalar, uluslararası boyutta çözülememiş problemler onların dünyasından uzak konulardır. Olay ağırlıklı olan çocuk edebiyatı mahsulleri, küçük okurları hikâyenin içinde tutmak gayretinde olmalıdır. Okumanın sevdirilmesi bu metinlerin amaçlarındandır. Zira Çocuk edebiyatı, çocuğun oyuna yüklediği anlamla yakın bir ilişki içindedir. Çocuk, edebiyat eserlerini okurken keyif alıyorsa okuma eylemini de sürdürecektir.

Çocuk edebiyatı eserlerinin hedef kitlesini çoğunlukla küçükler oluşturduğundan yazarların en hassas olması gereken konulardan biri de dil ve üsluptur. Dil ve üsluba dair yaklaşımlarda zaafiyet gösterilmesi, sorunlar yaratacaktır. Bu metinler, küçüklerin dil becerisini, hayal gücünü ve yaratıc1 düşünme yeteneğini geliştirmeyi amaçlar (Şimşek, 2006, s.543). Küçüklerin dünyasına hitap eden, daha çok somutlamayı ön plana çıkaran bir anlatım, cezbedici olabilir. Kelime hazinesi ve sözcüklerin seçimi de önemlidir. Yetişkinler de çocuk edebiyatı metinlerinin okuyucusudur. Bu metinleri sadece küçük yaştaki okurların okuduğu var sayılsa bile nitelikli bir toplumun inşasında çocuk eğitimi en önemli konulardandır. Zira birçok yetişkinin fark edemediği 'kralın çıplak' olduğu gerçeğini çocuk akl1/ yüreği/ bakış1/ duyarlılığı fark edebilmektedir. Bu bilinç; onun çıkarsız bakışında, hesapsız tutumunda ve cesaretli yapısında yatmaktadır.

Çocuk edebiyatı ürünlerindeki en problemli alan şüphesiz ki ideolojik yaklaşımlardır. Kaba ideolojik yaklaşımların ötekileştirici tutumu, çocuk psikolojisinde telafisi zor hasarlara yol açacaktır. Popüler olma kaygısı ya da eserlerin çok satılmasına dönük ekonomik odaklı bir yaklaşım da; küçüklerin ruhuna aykırı kimi konu ve olay örgülerinin ya da insan biçimlerinin ön plana çıkmasına ve böylece küçükler için olumsuz örneklerin özenilen bir konuma gelmesine neden olabilecektir. Bu yüzden argo 
söyleyişler ya da cinsellikle ilişkilendirilebilecek konular küçük yaştaki okurların sağlıklı gelişimini etkileyeceğinden romanlarda bu türden ifadelere yer verilmemelidir.

Estetik değeri olan çocuk edebiyatı mahsulleri; minik zihinlerde insani duyarlılığın, demokratik tutumların kök salmasına katkı sağlayacaktır.

Tanzimat'tan sonraki Türk edebiyatında çocuk müstakil bir konu olmaya başlar. Bunda her ne kadar Batı edebiyatının etkisi büyükse de yeni girilen medeniyet düşüncesinin toplumda kök salması ve yetişen yeni nesillerin bu yönde terbiye edilmesi düşüncesi de etkili olmuştur (Kerman, 1998, s.105). Şinasi'nin 1859 'da Jean de La Fontaine'nin fabllarından yaptığı çeviriler, bizde çocuk edebiyatının Batılı anlamdaki ilk örneklerini oluşturur (Anameriç ve Rukanc1, 2015, s.27).

Türkiye'de çocuk edebiyatının önemli bir ismi olan Gülten Dayığlu (1935), on beş yaşındayken yazmaya başlamıştır. Çocuk ve gençlik edebiyatı kapsamında elliyi aşkın eserin sahibi olan yazar, dokuz çocuk romanı kaleme almıştır. Bu romanlarda "hareketin ön planda olduğu serüven dolu bir kurgu ile çocuğa ve gence olumlu değer ve davranıșları kuru bir nasihat șeklinde değil, hayatın içinden seçtiği canlı örneklerle verir" (Sınar Çılgın, 2007, s.70). Yazar, çocuk edebiyatına katkılarından dolayı yurtiçinde birçok ödül almıştır. Çocuk edebiyatına katkı sağlamak amacıyla da 2007 yılında Gülten Dayığlu Çocuk ve Gençlik Edebiyatı Vakfı'nı kurmuştur. Vakıf, her yıl düzenlenen yarışmayla çocuk ve gençlik edebiyatının bir dalında ödül vererek bu alandaki eserleri teşvik etmeyi amaçlamaktadır.

Gülten Dayığlu'nun 1971 yılında yayımlanan ilk romanı Fadiş, günümüzde 80'i aşkın baskısıyla okurlarıyla buluşmaya devam etmektedir. Kırk beş yılı aşkın bir süredir birçok kuşakla buluşan, çocuk ruhunu ve duyarlılığını yansıtan önemli eserlerdendir. İki oğlu olan Dayığlu, bu eser yayımladığında romanın odak kişisi olan Fadiş'i, çocuklarına bir kız kardeş olarak sunacak kadar benimsemiştir. Dayığlu, romanı kendi yaşamından esinlenerek yazdığını belirtir (Sivri, 2014, 552). Bu önemine atfen 2001 yılında Fadiş'in 'doğumunun' 30. yılı münasebetiyle birkaç üniversitenin ortaklaşa düzenlediği ulusal bir sempozyum gerçekleştirilmiştir. $\mathrm{Bu}$ sempozyumda yazarın, çocuk edebiyatına katkıları tartışılmıştır.

Bu çalışmada, Fadiş adlı romanın çocuk dünyasını yansıtma biçimleri üzerinde durulmuştur.

\section{Fadiş'in Hikâyesinin Dramatik Kökenleri}

Fadiş romanı, Kurtuluş Savaşı yıllarında Yunanların Anadolu'yu işgaliyle başlar. Savaşta oğlunu kaybeden Naciye Kadın, kızı Cemile'yle beraber yeni bir yurt edinmek için Toruslu kasabasına göçer. Bir süre sonar Cemile, bu kasabanın terzisi Kâmil Bey'le evlenir. Kâmil Bey, evliliğe dair sorumluluklarını yerine getiren bir adam değildir. Bir süre sonra doğan Fadiş adlı kızı da Kâmil Bey’i evine bağlayamaz. Ailesini terk eden Kâmil Bey, şehre taşınır ve burada başka bir kadınla yaşamaya başlar. Annesini kaybeden Cemile, şehirde bulunan Kâmil Bey'in yanına getir. Fakat Kâmil Bey ne onu ne de kızı Fadiş’i sahiplenir. Bunun üzerine Cemile, kızı Fadiş’i de yanına alarak İstanbul'a çalışmaya gider.

Evlerde hizmetçilik yapmaya başlayan Cemile, kızının hor görüldüğünü fark eder. Bunun üzerine Fadiş'i, para karşılığında akrabalarının yanına gönderir. Roman boyunca Fadiş, birçok ev ve şehir değiştirir. Her gittiği yerde sahipsizliğinden kaynaklanan sıkıntılar yaşar. Romanın sonunda yatılı okula kaydedilen Fadiş, artık annesine de kavuşmuştur.

Çocuk romanları, genellikle olay ağırlıklı bir içeriğe sahiptir. Çünkü "bol macera, komik sahneler ve heyecan-gerilim unsurları" (Sağlık, 2005, s.253) küçük okurların ilgisini çeker. Fadiş romanı da olay ağırlıklı bir içeriğe sahiptir. Olay ağırlıklı kurgu, onların dimağının diri kalması ve heyecan unsurunun sürdürülmesi için gereklidir. Zira çocuk alg1sı, bu dönemde daha çok somut olgu ve olaylar üzerinden şekillenir.

Çocuk romanlarının özelliklerinden biri de kahramanın yaş bakımından küçük olmasıdır. Fadiş romanındaki olayların odağında da Fadiş adlı küçük bir kız yer alır. Diğer roman kişilerinin hepsi, Fadiş'le ilişkileri oranında kendilerine yer bulur. Fadiş’ten önce romanda yer alan kişiler de Fadiş'in dramatik yaşamının hazırlayıcısı konumundadırlar. Bu kişilerden olan Naciye Kadın, Fadiş'in ninesidir. Kurtuluş Savaşı sırasında "oğlunun şehitlik haberini almış. Bunun üzerine bir de evi yanınca, kolu kanadı 
kıııl(mıştır). Kızı Cemile'den başka kimsesi kalmamıştır." Anlatıcı daha romanın başında okura kimsesiz bir kadının tek kızının tek çocuğu olan Fadiş’i, zor bir hayatın beklediğini sezdirir. 'Erkeksiz' bir kadın ve kızı için zorlu yaşam olgusu Kurtuluş Savaşı yıllarına denk getirilerek yaşanacakların katlanarak bir trajediye evrileceği hissettirilir.

Fadiş; kendi evleri dışında babasının evinde, İstanbul'da annesinin hizmetçilik yaptığı Doktor Sami Bey'in evinde, Saime Hanımefendi'nin evinde, babasının teyzesinin kızı Gülsüm Hanım'ın Akkale'deki evinde, Bekçi Mustafa Dayı'nın evinde, İstanbul'da bir hemşerilerinin evinde, Hafize Nine'nin evinde, Tanardı'da bulunan amcası Hamdi Bey'in evinde ve son olarak da Örenköy'deki teyzesi Zehra Kadın'ın evinde kalır. Bu evlerin neredeyse tamamında hayatına tesir eden, sahipsizliğini açığa çıkaran dramatik bir olay yaşar. Olumsuz hadiseler karşısındaki tek tesellisi, sonunda annesine kavuşacağını bilmesidir. Yazar, mekânı genişlettikçe romana yeni kişiler dâhil olur. Bu da çocuk romanlarındaki olay ağırlıklı kurguyu belirginleştirir.

Fadiş'in dramının sebebi babası Kâmil Bey'dir. Küçük yaşta annesiyle köyden kente göçmesinin, annesinin hizmetçilik yaptığı evlerde horlanmasının ve annesinden ayrılmak zorunda kalmasının temelinde babasının sorumluluklarını yerine getirmemesi yatar. Tüm bunların sonucunda Fadiş, hem maddi hem de manevi bir yoksunluk içinde büyümek zorunda kalır. Çünkü Kâmil Bey, "başka babalar gibi değil"dir (s.37).

Kâmil Bey, bir babanın evladına yapabileceği tüm kötülükleri Fadiş’e yapmıştır. Ailesine sahip çıkmamış, başka bir kadınla yaşamaya başlamıştır. Tek derdi bir an önce Cemile'den boşanıp bu kadınla evlenmektir. Bu yüzden de sadece boşanmak için kızını defalarca kaçırmış, ona şiddet uygulamıştır. Fadiş, sadece babasından şiddet görmez. Gittiği her yerde sahipsizlikten ve babasızlıktan dolayı bir şiddet sarmalının ortasında kalır. Şiddete maruz kalmak Fadiş’i hayata küstürmez aksine o, her seferinde karşılaştığı olumsuz durumlardan daha da güçlenerek çıkmayı başarır. Bu yüzden de Fadiş, "sevilen bir kızdı(r)" (s.79), "çocuklar onu çok sevmektedir" (s.98) "iyimser bir kızdı(r)" (s.99). Bu güçlü özelliklere sahip yedi sekiz yaşındaki bir çocuğun, romanın küçük okurları için olumlu bir örnek teşkil ettiği söylenebilir.

Romandaki kötü baba, küçük yaşlardaki okurlarda babaya karşı olumsuz bir ön yargının açığa çıkmasına neden olabilecek düzeydedir. Çocuk zihinlerdeki baba imajının çok uç bir örnekle sarsıldığ söylenebilir. Anlatıc1, defalarca babaya iyi olma firsatı sunar fakat baba, her seferinde bu firsatları bencilce isteklerine feda eder. Babanın tek arzusu Cemile'den boşanmaktır. Bu yüzden de Cemile'ye "sana pek çok kötülüğüm dokundu. Daha gençsin, istersen ayrılalım" (s.32) diyerek yeni hayatına başlamak ve kızını tümden unutmak derdindedir. Sadece bir gece yanında kalan kızı Fadiş’i ertesi gün annesine teslim edip ondan kurtulmak ister. Zaten Fadiş de babasının hiçbir şeyine "inanmaz" (s.34). Anlatıcı, babalık açısından bu olumsuz durumu fark etmiş olmalıdır ki Kâmil Bey'in "başka babalar gibi olmadığını" (s.37) ifade etme gereği duyar. Fadiş’teki baba imajının sorunlu bir hal alabilecek bir düzeye taşınması, dramatik üslubun temelini oluştursa da romanın genelinde küçük okurlara verilmek istenen olumlu mesajlar hep bu olumsuz baba imajının gölgesinde kalacaktır.

Romandaki neredeyse tüm babalar, evlatlarına karşı olumsuz bir tutum içindedir. Fadiş’in babası Kâmil Bey; bencil, sorumsuz ve şiddete meyilli bir tipken Aydın'ın babası, otoriteyi karısına teslim etmiş edilgen bir kişiliktir. Hasan'ın babası Bekir Ağa olumlu bir tiptir. Ancak o da Fadiş konusunda çıkarcı bir kişi olarak karşımıza çıkar. Fadiş'le kavga eden oğlu Hasan ve karısı Zehra Kadın'a Fadiş'le ilgili takındıkları olumsuz tutumu desteklediğini "fakat Fadiş’i yollamak istemediğini”" (s.137) söyleyecektir. Çünkü Cemile'nin, kızı Fadiş için yolladığı parayı biriktirerek köyde ciddi anlamda tarım yapmaktadır.

Ali Kadir, Fadiş'e göstermiş olduğu sevgi ve merhametle ön plana çıkan en önemli kişidir. O, Fadiş'i Örenköy'e götürüp teyzesi Zehra Kadın'a teslim ederken karşımıza çıkar. Fadiş'in içinde bulunduğu kötü durumu gözlemlemiş ve annesinin "bir dağda babasının bir dağda" olduğunu ve bu yüzden "inci gibi bir yavru" (s.84) olan Fadiş’in de ortada kaldığını ifade etmiştir. "Kocamış" bir adam olan Ali Kadir ve eşi, çok istemelerine rağmen bir evlat sahibi olamamışlardır. Çocuklara karşı olumlu tutumuna rağmen Ali Kadir, bir baba değildir.

\footnotetext{
${ }^{1}$ Gülten Dayığlu, Fadiş, Altın Kitaplar Yayınevi, 35. Baskı, İstanbul, 2005, s. 10. Bu makalede sadece sayfa numarasıyla verilen alıntılar bu kitaba aittir.
} 
Baba imajının bu olumsuz yansımalarına rağmen anne imajı olumludur. Adeta baba imajının olumsuzluğu olumlu anne imajıyla giderilmek istenir. Ama olumlu anne vurgusu belirginleştikçe olumsuz baba olgusu kendisini daha fazla hissettirir.

Romanda birçok anne tipi söz konusudur. Bunlardan en önemlisi Fadiş'in annesi Cemile'dir. Cemile, kocasının kendilerini terk etmesine rağmen hayata tutunmak için muazzam bir çaba gösterir. O, kızına iyi bir gelecek sağlamak için çalışır. Zengin evlerde hizmetçilik yapar. Çocuğunu yanına alamadığı için kazandığı parayı çocuğuna bakan ailelere gönderir. Ancak Cemile, çocuğu için bunca gayreti gösterirken Kâmil Bey, her seferinde kızını kaçırarak genç kadının yerleşik bir düzene geçmesine mani olur. Bu da gittikleri her evde "Fadiş'in horlanması" sonucunu yeniden doğurur. Bu yüzden genç kadın endişelidir. Kızının kendisi için ifade ettiği anlamı şu iç monoloğdan öğreniriz:

Herkes, yaşamını sürdürmek için bir yol seçmiş. Yaşamak güzel. Güçlü bir amaç için çalıșmak, yașamı daha da güzelleștiriyor. Fadiş'im için, var gücümle çalışırım. Onu büyütür, belki de okuturum. Hele okuyup bir meslek edinirse... (s.42).

Cemile dışındaki anneler, çoğunlukla sadece kendi evlatlarına karşı sevgi dolu bir tutum içindedirler. Diğer annelerin, evlatlarına karşı besledikleri aşırı koruyucu tutum, çocukların sağlıssız bir gelişim göstermelerine neden olur. Anlatıcı, bu durumu Fadiş ve yaşıtları arasındaki farklılıklar üzerinden aktarır. Bu farklılıklar da duygusal gelişimle ilgilidir. Fadiş, Cemile'nin olumlu tutumu dolayısıyla daha ölçülü ve hayata karşı daha pozitif bir tutum içindedir. Oysaki aşırı koruyucu bir tutumla Aydın'ı büyüten annesi, Aydın'ın tutarsız, yalancı, çevresindeki her şeye zarar verecek bir kişilikte olmasına zemin hazırlar. Bu durum, Aydın'ın tutarlı davranışlar sergilemesini engeller. Zira Aydın, hayatta tek önemli şeyin zenginlik olduğuna inandırılmıştır. Zengin olmak, haklı olmanın yegâne şartıdır. Ona kendisinden fakir olanlara karşı kibirli bir tutum takınması öğretildiğinden o da kendisinden daha zenginler karşısında hep ezik kalacaktır. Ona göre mutluluk, ancak zenginlikle sağlanabilecektir. Hep daha zengin birileri olacağından mutluluk da hep gelecekte bir yerlerde olacaktır. Aydın, bu yüzden gerçek mutluluğun ne demek olduğunu, öğren-e-meyecektir.

\section{Çocuk Dünyası}

Çocuğun dünyaya bakışı, hayatı algılama biçimi ve farklılıklar karşısındaki tutumu yetişkinlere benzemez. Onun nesneleri algılama biçiminde herhangi bir yorumlama söz konusu değildir. Nesneler, küçüklerin zihinlerinde oldukları gibi kendine yer bulur. Bu nesnelerin anlamında herhangi bir mecaza yer yoktur.

Fadiş romanında çocukların dünyasına genişçe yer verilmiştir. Fadiş, yoksulluk içindeyken annesinin mutlu olduğunu hissettiği an "kıvanç içinde, annesini öpmeye başla(r)" (s.28). Onun bu 'beklenmedik' tepkisi, hayata saf ve masum bakabilen bir kalbe sahip olmasıyla açıklanabilir. Herhangi bir kişinin etkisinde kalmadan aldığı kararlar, katışıksız çocuk aklının bir sonucudur.

Anne ve babasının davranışlarına göre pozisyon alan Fadiş, anne ve babalık vasıflarının kendisindeki yansımasına göre yeni değerlendirmelerde bulunur. Annesinin kendisi için yaptığ 1 fedakârlıkları görerek ona karşı sonsuz bir sevgi beslemesine rağmen babasına karşı aynı duyguları beslemez. Annesinden uzakta olan Fadiş, yalnız kaldığında hep annesini düşünür. Bencil ve sorumsuz kişiliğinden dolayı kendisine sadece zarar veren babasını sevmez. "Nedense Kâmil Bey'e baba demeye dili varm(az)" (s.61). Bir evladın öz babasına baba demeye dilinin varmaması, kalbinde babalığa dair hiçbir olumlu hatıranın bulunmamasıyla ilgilidir. Baba bile olsa kötülük yapması halinde ona karşı olumlu duyguların tükenebileceğini görmekteyiz. Bu hadisenin odağında bir çocuk bulunuyorsa durum trajik bir hal almış demektir. Bu yüzden de Fadiş, "babasını bir türlü sevemiyor, ona 1sınamıyor", oysa gittiği "köyü, köylüleri çok seven" (s.64) bir kızdır.

Yazar, dış müdahaleler söz konusu olmadığında çocukların paylaşıma açık olduğu üzerinde de durur. Romanın Fadiş’ten sonraki önemli ismi Hasan, "on kuruşluk leblebi”, Fadiş de "on kuruşluk kuru üzüm” alır. Bu iki kuruyemişi karıştırdıktan sonra paylaşıp yerler. Kendi aralarında, herhangi bir büyüğün müdahalesi olmadan sahip olduklarını paylaşabildiklerinden diğer çocuklara göre gelecekte daha mutlu olacaklardır. Paylaşmayı bilmeyenler; daha bencil olacak, sahip olduklarının kıymetini bilmeyecek ve doyumsuz bir hayat sürdüreceklerdir. Roman boyunca oyun, yiyecek ve giyecek gibi olgular üzerinden 
çocuk gelişiminde paylaşımın önemi vurgulanır. Paylaşmayı bilenler çoğunlukla yoksullardır. Bu da paylaşmanın nicelikle değil nitelikle ilgili olduğunu gösterir.

Çocuk dünyası, emek üzerinden de yansıtılmıştır. Romanda çocuk emeğinin en belirginleştiği alan, doğadır. Onlar, doğa ile uyumludur. Doğanın kendi kanunlarıyla şekillendirdiği yaşam biçimini destekler bir ruh dünyasına sahiptir. Doğanın içinde büyüyenler, daha mutlu ve özgüvenlidir. Onların doğayla ilişkisi, oyunla ilişkilerine benzer. Kendilerine yüklenen sorumluluğu çok duyarlı bir şekilde yerine getirmeye dikkat ederler. Bu dikkat, oyundaki kazanmanın yerine geçer. Hasan'ın annesi, çamaşır yıkamak için Hasan'dan ve Fadiş’ten yardım istediğinde Hasan ve Fadiş söylenenleri hemen yapar. "Kazanın suyu azalınca dereden su alıp kazanı doldururlar" (s.107). Bu yolla sorumluluk almayı ve dayanışmanın önemini kavramış olurlar. Zira onların katkılarıyla gerçekleşen bir 'iş' söz konusudur.

Çalışmaya da oyun olarak baktıklarından yardımına gittikleri arkadaşlarına sanki oyun için gitmiş gibidirler. Hasan'ın Fadiş'e, "Bugün kimin harmanına gidelim?” (s.109) diye sorması, 'bugün kiminle oynamak istersin?'in yerine geçer. Hiçbir çıkar amacı olmadan, herhangi bir beklenti içine girmeden sergilenen bu davranışlar, onlardaki dayanışma duygusunun ne denli güçlü bir temele yaslandığını gösterir. Burada yardımlaşma ve dayanışmanın doğrudan doğruya emek üzerinden gerçekleşmesi de ayrıca önemlidir. Çocuklar, bu duyguyu gerçekleştirmek için para gibi herhangi bir nesnenin aracılığına ihtiyaç duymazlar. Tüm bu işleri yapanlarda "çevrelerine yararlı olmaktan doğan bir dirlik" (s.111) açığa çıkar.

Çocuklara sorumluluk yüklenmesi ve bunun sonucunda onların olumlu bir gelişim sürecine girmesi, çoğunlukla kırsal bölgelerde karşımıza çıkar. Kırsal bölgelerin ön plana çıkarılması, hem romanın gerçekçiliğini güçlendirmiş hem de çocuğun doğada dayanışma içinde bulunmaya daha meyilli olduğunu imlemiştir.

Hasan ile Fadiş’e bahçede büyük birer yer ayrılmıştı. Fadiş, bu küçük yeri çok benimsedi. 'Burası benim bahçem' diyerek toprak parçasını tablalara ayırdı. Buralara biber, patlıcan, domates fideleri dikti. Köşelere bal kabağ 1 çekirdekleri gömdü. Çevresine fasulye ve mısır ekti. Bütün bunları yaparken teyzesinden örnek aliyordu...

Bir sabah, birkaç fasulyenin, topraktan baş vermiş olduğunu gördü. Var gücüyle Hasan'a bağırıp durumu müjdeledi (s.147-148).

Çocuklara bahçede yer vererek onların bahçeyle ilgilenmelerini sağlamak Bekir Ağa'nın fikridir. Zehra Kadın "sofrada, 'bu yemek Fadiş'in bahçesinin patlıcanıyla yapıldı' deyince, dünyalar Fadiş’in olurdu. İki üç yapraklı fidelerin gelişip sebze vermesi, onu içten içe düşündürüyordu” (s.150). Bekir Ağa ve Zehra Kadın'ın köy yerinde, hiçbir eğitim almamalarına rağmen çocuk eğitimi konusunda bunca bilinçli olması dikkat çekicidir. Yazar, bunu şartların bir gereği olarak sunsa da aslında doğanın insanla ilgi her alanda daha sağlıklı bir sonuç açığa çıkardığı romanın derin yapısında kendisini hissettirir. Hasan ve Fadiş'in emeklerini günden güne, sabırla, olgunlukla takip etmesi ve sonuçlandırması, aslında onların doğadaki bitkiler gibi olgunlaşmalarının göstergesi olarak okunabilir.

\section{Çocuk Gelişiminde Oyun ve Masal Vurgusu}

Çocuk edebiyatının en önemli özelliklerinden biri de oyun vurgusudur. Oyun, onların sağlıklı bir şekilde büyümeleri için önemlidir. Zira "çocuğa hangi tür eğitim verilecekse verilsin bunun oyunla bir beraberliği olmalıdır” (Tökel, 2005, s.79). Küçüklerin doğasında bulunan oyun; onların eşyayı, insanı ve hayatı tanımasında ve anlamlandırmasında temel belirleyendir.

Çocuklar açısından modern yaşam ile geleneksel yaşam arasındaki fark, oyunlarda da görülür. Kırsal kesimlerde yaşayanlar, çocukluklarını gerçek oyun ortamlarında yaşarlar. Sanal gerçekliğin var ettiği modern dünyanın çocukları ise oyunlarını sanal ortamda oynamak zorundadır. Sokakla ve mahalleyle hatta hayatla temas etmeyen çocuk, arkadaş ortamıyla ancak okul çağlarında yüzleşebilmektedir. Geç dönemde gerçekleşen bu arkadaş ortamı kırsal bölgelere göre geridir. Kreşler ve ana sınıfları, bu açı̆̆ı bir nebze de olsa kapatır. Zira çocuk aklı, oyun odaklı işlevsel kılındığından oyunlar, onların arasında rahat iletişimin yerine geçer. Oyunla sayesinde gerçekleşen 'çıkarsız' ilişki, onların sonraki yaşamlarını olumlu etkileyecektir. 
Fadiş romanında oyunlar sokakta, mahallede hatta evde oynanır. Çocukların olduğu her yerde oyun da vardır. Onlar, büyüklerin olduğu ciddi ortamlarda bile, sonuçta bir şekilde cezalandırılsalar da, oyun oynamaktan kendilerini alamazlar. Yazar, onların hayatı oyun olarak algıladıklarını belirginleştirerek oyun ve pedagojik gelişim arasındaki ilişkiyi imler.

Sahipsiz bir şekilde büyümek zorunda olan Fadiş'in gelişimi, oyunlar sayesinde sağliklı bir düzlemde ilerler. $\mathrm{O}$, yabancısı olduğu yerlere gittiğinde bu sayede kendisine arkadaş bulur ve kişiliğini gösterir. Örenköy'deki ilk gününde sokağa çıktığında derin bir yalnızlık içindedir. Ancak onu gören Habibe ve Feten adlı kızlar "gel, oynayalım, dediler. Kızların ellerine sımsıkı yapışan Fadiş’in içi sevinç ve coşkuyla doldu" (s.98). Oyun sayesinde ilk defa girdiği ortamda kabul gören Fadiş, yine oyun sayesinde olumlu kişiliğini gösterme imkânı yakalar.

O günden sonra Fadiş, mahallede kendi yaşındaki tüm kızlarla ve oğlanlarla arkadaş oldu. Köylü çocuklar onu çok seviyorlardı. O, sokağa çıkmadan hiçbir oyun kurmuyor, aralarına katılmasını bekliyorlardı (s.98).

Oyunlar, sosyalleşmenin önemli bir unsuru olarak sunulmuştur. Fadiş, "iyimser” bir kız olduğu için "oyunlarda mızıkçılık yapmaz, hep haklıdan yana" bir tutum takınır. Onun olumlu tutumu sadece onun değil arkadaşlarının da gelişimine katkı sağlar. "Kavga etmek isteyen arkadaşlarına engel olup kavgacıları yatıştırmayı" (s.99) bilir.

Oyunlar genellikle bir grup içerisinde sorumluluğun paylaşılmasıyla oynanır/ kazanılır. Bu, çocukların hem eğlenmesini hem de başarının ortak çalışmayla elde edileceğini öğrenmelerini sağlar.

Gülten Dayığlu, oyunların gelişim üzerindeki etkisini Fadiş özelinde vurgular ve oyunların, ancak grup içinde bir amaca dönük olduğunu belirtir. Örenköy'de oyunlar genellikle grupla beraber oynanır. Bu yerde tek başına oynayan bir çocuğa rastlanmaz. Aslında yazar, bu vurguyla modern dünyanın tek başına oynamak zorunda olan çocuklarına göndermede bulunmuş gibidir.

Romanda, oynanan kimi oyunların adına ve bu oyunların oynanma biçimine ayrıntılı bir şekilde yer verilmiştir. Bu oyunlar: "evcilik, beş taş ve longoz" adlarını taşır. Anlatıcı, oyunları ayrıntılı bir şekilde anlatarak bunların hem gerçek olduğunu hem de küçük okurların bilmeseler bile bu oyunları oynayabileceklerini vurgular. Bu yolla günümüz çocukları için oyunların ulaşılmaz, hatta 'gerçeküstü' olduğu algısı sarsılmaya çalışılır. Gerçek oyunlar oynayarak sağlıklı bir çocukluk dönemi geçirmek için önemlidir. Romanda oynanma biçimlerine yer verilmeyen ama adlarından bahsedilen oyunlar da vardır. Ayrıntısına girilmeyen ebecilik ve sek sek gibi oyunların diğer oyunlara nazaran daha yaygın oldukları söylenebilir.

Oyunların grupla oynanması, çocuklardaki paylaşım duygusunu ve sorumluluk algısını olumlu yönde etkiler. Oyunların bu özelliği kent ortamında büyüyenler için neredeyse kurmaca bir anlam ifade eder. Zira televizyon, adeta bebekler için bakıcılık görevi üstlenmiştir. Gençlik ve yetişkinlik dönemlerinde de televizyondan uzak kalmak neredeyse imkânsız bir hal almıştır. Televizyona olan bağımlılık, şekil değiştirerek bilgisayara bağımlılık biçimine evrilmek üzeredir. Netice itibariyle her ikisinde de bir ekran karşısında yalnız kalma durumu söz konusudur. İnternetin insanların hayatına girmesiyle de buna bir de fiziksel zarar da eklenmiştir denebilir.

Çocukların oyuncak olarak tabiatta bulunan çeşitli nesnelere yönelmesi, doğayla temas etmelerine olanak tanımasından dolayı onların daha sağlıklı olmalarını sağlar. Doğada bulunan taş, toprak ve çamur gibi nesnelerle temas eden çocuklar, kendi emeklerinin ürünü olan yeni sonuçlara ulaşırlar. Özellikle "çamurdan firın, çanak, çömlek" vurgusu, yaratıcı fikirlerinin, doğal akışına bırakıldığında açığa çıktığı belirtir. $\mathrm{Bu}$, anlatıcının vurgusundan ziyade oyunların doğasında vardır.

Oyunlara verilen isimler de oyun oynanan nesnelerle uyumludur. Oyun nesnelerinin doğal olması çocukları doğaya daha fazla yaklaştırır. Bu bağlamda evcilik oyununun açık mekânlarda oynanan bir oyun olması önemlidir. Onlar, bu yolla tabiata karşı daha saygılı bir tutum takınacaktır. Bir diğer oyun olan beş taş, ritmik hareket etme, başarmak için odaklanma becerilerini geliştirecektir. Longoz, oyununun temel nesnesi olan boynuz, doğada bulunan nesnelerden faydalanmanın yerine geçer. Hayata oyun olarak bakan küçükler, atık durumda bulunan boynuzu bir eğlence nesnesine dönüştürmüştür. Oyun adları ve oyun nesneleri arasındaki sıradan fakat doğrudan bilişsel durum, onların çevreyi anlamlı bir bütün olarak algılamasına yardımcı olur. Çocuk, oynadığı oyunlar sayesinde farkında olmadan doğal yaşamın bir parçası olduğu bilinciyle hareket eder. 
Görselliğin doğal şartların sağladığı imkânlar dâhilinde gerçekleştiği kırsal dünyanın oyunları, yapaylığı bünyesinde barındırmaz. Bu yüzden de bir taş parçasının "yalancıktan" bir bebek olarak düşünülmesi onların "gerçek bir ana içtenliğiyle öpülüp okşanmasına" engel olmaz. Bu yolla kimi oyunların kurmaca yapısı, aslında küçüklerin gerçeklik algılarını güçlendiren bir pekiştireç görevindedir. Yazar, göndergesi olan oyunları bilinçli bir şekilde işleyerek romanın derin yapısında ciddi bir genişleme sağlamış, oyun ve çocuk arasında doğadan beslenen doğal ilişkiyi küçük okurların bilinçaltına kodlamıştır.

Masallar sağlıklı gelişim için önemli işlevlere sahiptir ve çocuk edebiyatının belli başlı dallarından birisidir (Meriç, 1986, s.321). Büyüklerinden masal dinleyerek yetişenler, ait oldukları toplumun gelenek ve görenekleriyle, eğlence ve espri anlayışlarıyla büyüyecek ve toplumla uyumlu bir gelişim süreci yaşayacaktır. Hayal dünyasını işlevsel kılan masallar, yaratıcılığa katkı sağlayacaktır.

Fadiş romanında eğitimin önemli bir bütünleyeni olan masal olgusuna da yer verilmiştir. Ancak bu, bütün bir masalın romana yerleştirilmesi şeklinde değildir. Yazar, sadece masal türünün anlatıcısından ve masalın çocuklar üzerindeki etkisinden söz etmiştir.

Halk edebiyatının bir türü olan masalların anlatıcısı kadınlardır. Yazar da masal anlatıcılarının kadın olduğu gerçeğinden hareket eder. Bu yüzden de romandaki masal anlatıcıları kadındır. Genellikle uzun kış gecelerinde çocukları eğlendirirken eğitmeyi amaçlayan masal, bu romanda da kış mevsiminde karşımıza çıkar. Hafize Nine, kış mevsiminde dişarıya çıkamayan Fadiş'e masal anlatır. O, "bütün masalları ikişer üçer kez anlatmıştı(r)" (s.50). Çocuklar, benimsedikleri masalları defalarca dinleseler de sıkılmazlar. Benimsedikleri masaldaki her kelime, onların hafızasında bir bütünün parçası gibidir. Defalarca dinledikleri masalın kelimelerindeki değişimi fark ederler. Bu değişimi fark etmelerinin sebebi masalın ilk anlatımı üzerinden zihinlerinde kurguladıkları dünyanın değişmesini istememeleridir ya da aynı masalın aynı kelimelerle anlatılmasını isteyerek düşsel derinliği korumak düşüncesindedirler. Her çocuk, zihinsel öngörüsünün el verdiği nispette bunu yapabilecektir. Ayrıca masalın var ettiği âleminin verdiği keyiften başka, masalın anlatımına da bir oyun gözüyle bakarlar. Masalın sözcüklerindeki değişimi yakalamaları kendilerini masalın bir parçası olarak görmeye başladıklarının da yerine geçer.

Romanın odak kişisi Fadiş, sahipsizliğin sebep olduğu yalnızlık ve dışlanmışlık anlarında "sokağa firlayıp yol boyunca koşmak, kaçıp uzaklaşmak" ister. Ancak Hafize Nine'nin anlattığı masallardaki "kurtları, haramileri, iğneli beşikleri, devleri, cadıları" (s.95) hatırlayınca kaçma fikrinden vazgeçer. Gerçeküstü yaratıkların Fadiş'in hafızasında korkutucu bir figür olarak yer edinmesi olumsuz bir yaklaşımın ifadesidir. Fakat yazar, bu olumsuzluğu küçük yaştakilere daha fazla zarar verebilecek yanlış bir davranışın meydana gelmesinde bir engelleyici olarak kullanır.

Anlatıcı, romanın sonlarında yeniden masal türünün önemi üzerinde durur ve masala dair yapılan vurguları çok gerçekçi bir şekilde yansıtır. Çocuklar, masalın kimi korkutucu öğeleri karşısında bile eğlenebilmektedirler.

Gece oturmaları, çocukların en sevdiği şeydi. Oturma evlerinde bir masal anası olurdu. Bu kadın, o denli tatll, heyecanlı, gülünç, korkunç masallar anlatırdı ki... Onu dinlerken çocukların solukları kesilirdi (s.143).

Yazar, halk edebiyatının eğitici ve eğlendirici bir türü olan bilmecelere de yer vermiştir. Bilmeceler, yetişkinler için olduğu kadar küçükler için de "eşyanın, nesnelerin canlandırıldığı, konuşturulduğu; içinde sırlar taşıyan bir şiir cenneti, bir bilgi yarışması, eğlendirici ve öğretici bir oyundur” (Köktürk, 2005, s.129). Romanda bilmecelerin yaratıcı düşünme yeteneğini öne çıkarması vurgulanmıştır. Hasan, "okuma kitabını açıp bilmecelerin yanıtlarını okudu. İki çocuk yeniden sevinçle kucaklaştılar" (s.100). Eserde bilmece ve eğitim arasında bir ilişki kurulması önemlidir. Bilmeceler üzerinden okul, okul kitapları ve okumanın gerekliliği vurgulanmıştır. Okula gittiği için okuma-yazma bilen Hasan, okula gitmeyen ve bu yüzden okuma-yazma bilmeyen Fadiş'e bilmeceleri soran kişidir. O, aynı zamanda bunların cevaplarını kitaptan da okuyabilmektedir. Okul üzerinden etken ve edilgen roller arasında bir ilişki kurulmuştur. Zira okuma-yazma bilen Hasan, bu bilgisiyle soran pozisyonundadır. Bilmecelerin cevapları kitapta yazmasına rağmen okuma-yazma bilmeyen Fadiş, yazılı cevapları okuyup anlamlandıramamıștır. Bu yüzden o, bir an önce okula başlamak arzusundadır. Okula gitmenin daha doğrusu eğitimin ne kadar önemli olduğu, eserde bilmeceler sayesinde vurgulanmıştır. 


\section{Dini ve Milli Unsurlar}

Çocuk romanlarında ön plana çıkan konulardan biri de dini ve milli değerlerdir. Çocuğun yaşadığı toplumla arasında duygusal bağ kurulması için başvurulan bu yol, onun yaşadığı toplumda yabancılık çekmemesinin yerine geçer. Küçük yaşta aidiyet duygusunun gelişmesi, gelecek için daha sağliklı bir kişiliğin anahtarıdır. Değerleriyle büyüyen nesiller, ait oldukları toplumun geleceğe taşınmasında sorumluluk alırlar.

Fadiş romanında dini değerler, toplumsal karşılıklarıyla verilmiştir. Toplumun genelinde kabul görmüş yaklaşımlar söz konusudur. Atasözü ve deyimler üzerinden bir din duygusu aşılandığ söylenebilir. Fadiş ve Cemile'nin en sıkıntılı zamanlarında önlerine çıkan yeni bir fırsatı ifade etmek için "Kul bunalmayınca Tanrı yetişmez" (s.28) atasözüne yer verilmiştir. Verilmek istenen din duygusunda herhangi bir aşırılık söz konusu değildir.

Çocuklara verilmek istenen din duygusu, hem toplumda hem de küçüklerin dünyasında karşıllğı olan bir düzleme sahiptir. Hemen hemen her büyügün anılarında Ramazan orucunun yeri vardır. Ramazan orucuyla çocuklarda görülen heyecan, başarılı/ gerçekçidir. Oruç tutmaları için Fadiş ve Hasan'a "Bu gece, sahura sizi de kaldıralım mı?" diye sorulunca onlar, "Ne olur kaldırın!" diye Bekir Ağa ve Zehra Kadın'a yalvarırlar (s.115). Böylece Zehra Kadın, orucun nasıl tutulması gerektiğini ve nelerin orucu bozduğunu anlatmaya başlar. Dini anlayışın bir bütün olduğunu ifade etmek için de "namazsız oruç olmaz" şeklinde bir uyarı yapar.

Ramazan ayındaki çeşitli dini ritüellere de yer verilmiştir. Çocukları heyecanlandıran ritüellerden biri de ramazan davulcusudur. "Uzaktan bir davul sesi yayıldı. Çocuklar sevinçle birbirine baktılar. Onların sevincini gören Bekir Ağa:

-Bu sahura kalkma davulu, dedi. Biraz sonra da imsak davulu çalacak. O zaman artık oruç başlamış olur. Ağza bir şey alınmaz" (s.116).

Anlatıcı, Ramazan ayına dair unsurları hayatın olağan akışı içinde verir. Büyükler, çocukluk dönemlerini özlerken; küçükler, oruç zamanının gelmesi için heyecan içindedirler. Aşağıdaki paragraf, Anadolu'da oruç ve çocuk arasındaki ilişkinin bir oyun olarak başladığını, din duygusunun küçüklükten itibaren geliştiğini ifade eder:

Köyde, Ramazanın ilk günü, yedi yaşını geçmiş tüm çocuklar oruç tutardı. Hepsi de oruçlarıyla ögünür, inanmayan olursa:

-Nah! diye dillerini dışarıya sarkıtırlardı. Pek çoğu, bunun niçin yapıldığını, dilden orucun anlaşılıp anlaşılmadığını bilmiyordu. Öyle görmüştü, öyle yapıyordu (s.117).

Küçükler de büyükler gibi iftarda "Bismillahla birer lokma ekmek kopardılar. Bu lokmaları, pancar pekmezine banıp oruçlarını bozdular" (s.123). İlk orucun küçüklerin dünyasındaki yerini anlatan anlatıcı, samimi bir din anlayışında çocukça bir masumiyet olduğunu belirginleştirir. $\mathrm{Bu}$ din anlayışı, sevgi temellidir, hesap üzerine inşa edilmemiştir, çıkara dönük bir beklentiyi karşılamak amacında değildir.

Anadolu'da küçüklerin oruç tutmaya alışması için çeşitli yöntemlere başvurulur. Bunlardan birisi de birçok yetişkinin geçmiş anılarında saklı duran "tekne orucu (öğleye kadar tutulan çocuk orucu)"dur.

Anlatıcı, din sevgisi üzerinden temizlik alışkanlığına vurgu yapar. Orucun açılması için öncelikle ellerin yıkanması gerektiği ya da "arife günü yıkanan çocukların, arpa boyu uzadıkları" (s.130) dini duyarlılık üzerinden temizlik alışkanlığının kazandırılmasına dönük bir anlayışı ifade eder.

Milli değerler, romanda Cumhuriyet Bayramıyla karşılık bulur. Ayrıca Cumhuriyet Bayramıyla Ramazan Bayramı aynı döneme denk getirilmiştir. Romandaki bu çakışma, dini ve milli duyguların bir arada önemli olduğunu gösterir. Örneğin hem dini hem milli bayram münasebetiyle küçüklere "avuç avuç yemiş" dağıtan köy imamıdır. Cumhuriyet Bayramını kutlamak için köye kaymakamın geldiği görülür. Bu da devlet-millet bütünleşmesinin önemine işaret eder.

Milli duyarlılığın yerleşmesi amacıyla Atatürk sevgisine de yer verilmiştir. Çocuklar için milli bir kahramanın varlığı, onlardaki güven duygusunu besleyecektir. Atatürk, çocukların örnek alması gereken somut bir kişilik olarak yansıtılır. Romanın vaka zamanının Kurtuluş Savaşını takip eden birkaç yıl olduğu düşünüldüğünde Atatürk vurgusu, daha gerçekçi bir düzleme taşınmış olur. Kaymakamın Cumhuriyet Bayramı münasebetiyle yaptı̆̆ konuşma şu şekildedir: 
Yavrularım. Atatürk'ümüzün bin bir güçlükle düşmandan kurtarıp yeniden kurduğu güzel vatanımızı sizler koruyup yücelteceksiniz. Bunun için, çok çalışmanız gerek. Başarıya, dürüst ve çalışkan insanlar erişebilir. Cumhuriyet Bayramınız kutlu olsun (s.155).

Görülmektedir ki yazar, çocukların çalışkan, dürüst, erdemli birer insan olmasını hem dini ve hem de milli değerler üzerinden sağlamaya çalışmıştır.

Askerlik konusu da romanda yer verilen milli konulardandır. Özellikle Anadolu'da davullu eğlencelerle askere yollama şu şekilde söz konusu edilmiştir:

Askere giden gençler köyden ayrılıyorlardı. Delikanlılar, çıkınları sırtlarına sarıp bir kamyona doluşmuşlardı. Oğulları askere giden ana babalar ve onları uğurlayan köy halkı, yavaş yavaş ilerleyen kamyonun arkasından gidiyorlardı. Kamyonun önünde gençlerin söylediği askerlik türkülerine eşlik eden davulcu yürüyor ve var gücüyle tokmağı davula indiriyordu. Bu neşeli kalabalık, genç askerleri köy dışına kadar uğurlayacaktı (s.108).

Oğlunu askere yollayan anne ve babaların ayrılığa rağmen mutlu olması, askerliğin kutsal bir vazife olarak görülmesinden dolayıdır. Bu tören havasındaki uğurlama, aynı zamanda sonraki nesillerin de aynı coşku ve heyecanla askerlik görevini yapmak için isteklenmelerini amaçlar. Bu yüzden de Hasan, "asker uğurlama törenine bayılırdı. Böyle günlerde, kalabalığın arasına karışınca asker olacağı günü düşlerdi” (s.108). Yazar; asker, askerlik üzerinden vatan ve vatan savunması kavramlarının önemini çocuklara şenlik havasında sunarak hem bir gerçekliğe hem de bir sorumluluğa göndermede bulunmuştur.

\section{Dil ve Üslup}

Çocuk edebiyatının en ayırt edici özelliklerinden biri, dil ve üsluptur. Çünkü "nitelikli, sanatçı duyarlılığıyla hazırlanmış çocuk kitapları; anadilinin yapısının, kural ve anlatım olanaklarının çocuklara sezdirilmesi ve kavratılmasında başat bir sorumluluk üstlenir" (Sever, 2013, s.91). Ana dili gelişimi için önemli olan çocuk edebiyatı, yaygın bir şekilde kullanılan atasözü, deyim ve ikilemelere yer vermelidir. $\mathrm{Bu}$, küçük bireylerde ana dili sevgisinin yerleşmesi için gereklidir.

Hâkim bakış açısıyla kaleme alınan Fadiş romanında çoğunlukla öyküleyici anlatım tekniğine başvurulmuştur. Küçük okurlar, öyküleyici anlatım üzerinden geliştirilen merak unsuruyla romanın içinde tutulmuştur. Bu yüzden de romanda diyalog tekniği kendisini fazlasıyla hissettirir. Yer yer betimleyici ve açıklayıcı anlatıma da yer verilmiştir. Betimleyici ve açıklayıcı anlatım teknikleriyle bilgiler verilmiş, küçük bireylerin hayal dünyasının zenginleşmesi sağlanmıştır. Açıklayıcı anlatım, küçük okurların romandan kopmasına neden olacak düzeyde değildir. Bilakis küçük okurların olay örgüsüne hâkim olmasına aracılık eder. Oyunlara değindiğimiz bölümde oyunlarının oynanmasına dair ayrıntılı açıklamalara yer verildiği görülmüştü. Bu gibi açıklamalar, kurgu içinde işlevsel bir görev yüklenerek roman kişilerinin sıradan günlük yaşamlarını da yansıtır.

Gülten Dayığlu, Fadiş romanında sade, yalın ve anlaşılır bir dil kullanmıştır. Anlamın bulanıklaşıp yok olmasına yol açan uzun cümlelere yer vermemiştir. Yazarın kısa cümle tercihini göstermesi açısından aşağıya aldığımız paragraf, 34 kelime ve 8 cümleden meydana gelmektedir. Görüldüğü üzere yetişkinler için kaleme alınan metinlerde çoğu zaman bir cümleye karşılık gelen sözcük sayısı, çocuklar için yazılmış olan bu metinde 8 cümleyle ifade edilmiştir:

İkisinin de karınları acıkmıştı. Fadiş'in rengi sapsarıydı. Annesine ne açlığını söylüyor, ne de bir şey soruyordu. Cemile iki simit aldı. Birer tane yediler. Bir saat kadar orada dikildiler. O bir saat Cemile'nin içine işledi (s.31).

Romanın kelime dağarcığı hedef olarak seçilen okurlar için özenle oluşturulmuştur. Kimi yerde geçen mahalli ifadeler parantez içi tekniğiyle açıklanmıştır. Bu teknik, çocukların şivelerine bir sonraki adımda ise ana dillerine karşı daha ilgili olmalarına yardımcı olur. "Emme senin adını sevdik", "beni bazı Habiş diye ünlüyorlar" (s.98) örneklerinde görüldüğü gibi hem kelime hem de cümle bazında şive unsuru kendisini gösterir. $\mathrm{Bu}$ da roman kişilerini daha gerçekçi bir düzleme taşımıştır.

Roman kahramanlarının adları, çocuk dünyasındaki sempatik bir değişimi ifade Eder. "Fatma" ya da "Fadime", Fadiş olarak, Habibe, Habiş olarak değiştirilmiştir. Çocuk dilinde bir uyarlama olarak düşünülebilecek bu değişim, küçük okurlarla roman kahramanları arasında bir özdeşim kurulmasına 
yardımcı olur. Küçük okur, bu isimlendirme sayesinde roman boyunca Fadiş’i yakın bir arkadaşı olarak görmekte ve her adımında onun yanındaymış gibi hissetmektedir.

Romanda "teyze, ana yarısıdır" atasözüne; "kuş gibi çırpınmak", "lapa lapa kar yağmak", "yollara düşmek”, "ölçüp biçmek”, “yüzü gülmek”, "dili varmamak” gibi birçok deyime yer verilmiştir. Kullanılan atasözleri ve deyimlerin tamamı cümlenin bağlamına uygundur. Bu deyimler, verilmek istenen mesaj1 besler. Ayrıca "tatlı tatlı", "lapa lapa", "yavaş yavaş" gibi ikilemelere yer verilmiş ve çocuklar açısından dilin daha işlevsel kullanılmasının önü açılmıştır.

Romanda nadir de olsa argo söyleyişlere yer verilmiştir. Sami Bey’den kızı Fadiş'i almak isteyen Cemile, Sami Bey'in "şimdi piçinle seni tekmeyle sokağa atarım" (s.44) biçimindeki tepkisiyle karşılaşır. Burada kullanılan argo, hakaret amaçlı, ötekileştici bir yaklaşımdır. Kötülerin kişilikleri, kullandıkları kötü sözcüklerle yansıtılmıştır. Kullanılan argonun bir erkek ağzından bir kadına ve kız çocuğuna karşı kullanılmış olması toplumun cinsiyetçi bakışının yerine geçer. Cemile ve kızının çektiklerini duyan Bekçi Mustafa Day1, kendisini tutamayarak "şuncacık çocuktan ne istediler be Allahsızlar" (s.45) sözleriyle tepkisini belli eder. Bekçi Mustafa Dayı'nın iyiler safında yer alması, kullandığı argo ifadenin muhataplarının bu sözü hak ediyor olması ve bu ifadenin toplumda yaygın bir şekilde kullanılması gibi sebepler, bu ifadeyi argo olmaktan uzaklaştırmıştır.

Fadiş romanında anlatım, imla ve noktalamaya dair kimi yanlışlıklar da söz konusudur. "Bu nedenle bebeğin adını Cemile koydu" (s.11) cümlesinin anlamı açık değildir. Bu durum, cümlede bir anlatım bozukluğuna yol açmıştır. "Onun da içine güve yayıldı" (s.31) cümlesinde kelime yanlışlığı, "hepsi de oruçlarıyla öğünür, inanmayan olurlarsa" (s.116) ifadesindeki gibi kimi ek fazlalıkları da anlatım bozukluğuna yol açmıştır. Siklıkla görülen yanlışliklardan birisi filimsilerden sonra virgül kullanılmasıdır. "Olur, deyip, başka söze geçti”, "sol eliyle sağ eline su döküp, yüzünü yıkadı” (s.90) cümleleri bu duruma örnek gösterilebilir.

Şiddet, çocuk romanlarında dramatik unsuru derinleştirmek için başvurulan bir yoldur. Çoğunlukla anneler, yaramazlık yaptıklarında ya da kavga ettiklerinde evlatlarını döverler. Ancak, şiddetin tekrarı ve insan vücudunda geçici ya da kalıcı izler bırakacak şekilde tasviri küçük ruhlarda derin hasarlar bırakabilmektedir. Ayrıca sözlü şiddetin de kurguda geniş bir şekilde işlenmesi, çeşitli olumsuzluklara yol açabilecek düzeydedir. Odak kişi Fadiş, sıklıkla tekrarlanan bir şiddet sarmalının ortasındadır. Fadiş’e hem sözlü hem de fiziki şiddet uygulayanların başında babası gelmektedir. "Eğer bir daha ananın adını anacak olursan, seni trenden atarım" (s.36), "Kâmil Bey yerinden firlayıp Fadiş’i iyi bir patakladı. Yavrucağın bir yanağı ile üst dudağı şişip morarmıştı" (s.66) şeklinde baba şiddetine maruz kalan Fadiş, başka kişilerden de şiddet görür. Bu kişiler, Fadiş’in yanlarında kaldığı ebeveynler ve onların çocuklarıdır.

Fadiş, babası dışındaki kişilerden de sözlü şiddet görür. Özellikle "hizmetçinin kızı" olmasından dolayı aşağılanır. Yedi sekiz yaşlarında bir çocuğun bu denli sözlü ve fiziki şiddete maruz kalması, aşağılanması okur üzerinde mağduriyetten dolayı bir sahiplenmeye yol açsa da uzun vadede bu durumun küçük okurlar üzerinde neden olacağı hasar kaçınılmaz olacaktır. Romanın belki de okuru ikna etmekte zorlandığı tek yer Fadiş'in yaşadığı onca sıkıntıya rağmen hem bedenen hem de ruhen oldukça sağlıklı bir çocuk olarak hikâyesini tamamlamasıdır.

\section{Sonuç}

Yayınlandığından bugüne onlarca baskı yapan Fadiş, farklı kuşakları kapsayacak geniş bir okur kitlesine ulaşmıştır. Bu gerekçelerden dolayı eserin analitik bir yaklaşımla incelenmesi gerektiği kanaatine varild1.

Eserde her yaştan roman kişileriyle karşılaşılsa da kahramanların küçük yaşta olması hedef seçilen okur kitlesinin küçük okurlar olduğunu gösterir. Romanın kapağındaki resim ve yazı puntosunun büyüklüğü hedef kitlenin 12-15 yaş aralığındaki küçük okurlarını işaret eder. Kapak hariç, romanda herhangi bir resme veya fotoğrafa yer verilmemiş olması da bu düşüncemizi destekler. Yetişkin okurların çocukluk anılarında karşılığı olan ama günümüzde hayatın olağan akışı içinde pek rastlanmayan masallar ve oyunlar, romanın okur profile için oldukça ilgi çekicidir. Bu durum, küçük okurlarda eski zamanlara dair bir imrenmeye yol açacak düzeydedir. Buradan hareketle 'çocuk edebiyatı' gibi bir başlığın uygunluğu tartışılabilir. İnci Enginün (1991) gibi kimi araştırmacılar, bu şekildeki bir tasnifi doğru bulmaz. Sadece çocukların okuması için ayrı bir edebiyat yaratmanın doğru olmadığını düşünür. Yalnız 
küçük yaştaki okurların hedef olarak görülmesi "gelip geçici mahitette kaldığı, sürekli bir tesir göstermediği görülür” (Enginün, 1991, s.392). Gerçekten de Fadiş, her ne kadar belli yaştaki küçük okurlar için kaleme alınmışsa da yetişkinlerin de kendilerinden, geçmişlerinden bir şeyler görebildiği bir eserdir.

Çocuk edebiyatı, küçük okurları yetişkin yazınına hazırlayan bir geçiş yazını olarak da düşünülebilir (Aslan, 2008, s.38). Bu yüzden de özellikle küçük okurların meraklarından beslenen karakterde olması gereken bu metinler, yetişkinler için yazılan metinlereden çok daha hassas bir duruma işaret eder. Fadiş özelinden hareketle çocuk edebiyatında olması gerekenler ve olmaması gerekenler biçiminde bir tasnif yapmak bir gerekliliktir. Küçük okurların dünyasına yine onların duyarlılığıyla, onlara göre yaklaşmak esastır. Gülten Dayığlu, Fadiş’te bunu başarılı bir şekilde gerçekleştirmiştir. Olmaması gerekenlerde ise kimi sorunlu alanlar olduğu görülür. Romanda özellikle şiddet unsuruna fazlasıyla yer vermesi, sakınılması gereken bir durumdur. Kimi olumsuz ebeveyn örneklerinin de küçük okurların hafızasında olumsuz durumların açığa çıkmasına yol açabilecek düzeydedir.

Çocuk edebiyatı konusunda yetkin bir isim olan Gülten Dayığlu, küçük okurlar için yazdığ 1 Fadiş adlı ilk romanıyla bu alanda yazacağ önemli eserleri haber vermiş gibidir.

Roman kahramanı Fadiş'in hikâyesi, roman boyunca merak unsuruyla şekillenir. O, küçük olduğu halde birçok mekâna yolculuk yapar. Sahipsiz ve yoksul olmasından dolayı gittiği her yerde baskılara maruz kalır. Buna rağmen gittiği yerlerde yeni şeyler öğrenir. $\mathrm{Bu}$ da o yaştakiler açısından gelişim sürecinin bir süreklilik arz ettiğini vurgular. Zira Fadiş'in çocukça ilgisi ve duyarlılığı, yaşadığı sıkıntılara rağmen onu ayakta tutan tek şeydir. Olay örgüsünün çok yönlü bir düzleme sahip olması, roman kişilerini çeşitlendirmiş ve farklı kişilikteki yetişkin ve çocukların hayata bakışlarındaki zenginliği gözler önüne sermiştir.

Çocukların yetişmesinde ebeveyn tutumları önemlidir. Yeni nesil, bu tutumlarla yetişip kişilik kazanır. Hayata tutunmak için Fadiş’ten başka kimsesi olmayan Cemile'nin, kızına karşı gösterdiği sevgi ve şefkat, onun da hayat karşısında yapıcı bir rol yüklenmek istemesine kaynaklık eder. Ancak, romandaki olumsuz baba figürü, fazlaca 'abartıldığından', küçük okurlarda babaya/ babalığa karşı bir ön yarg1 oluşturabilecektir.

Roman, çocuk dünyasının en önemli tamamlayanı olan oyun ve masal gibi unsurlara yer vererek bu olguların gelişim üzerindeki etkisini belirginleştirmiştir.

Dini ve milli konular, romanda genişçe işlenmiştir. Romanda ifade edilen dini formasyon, geleneksel düzlemde ilerler. İdeolojik bir propaganda mahiyeti taşımaz. Çocuklar, dini bilgiler edinirken ve bunları uygularken oyun oynar gibidirler. Aynı şekilde milli kimliğin inşa süreci de küçük yaşlarda, okulda, çevrede yaşanan olgular üzerinden yaşamın doğal seyri içinde karşımıza çıkar. Bu yüzden de dini ve milli konuların işlenmesi oldukça gerçekçidir.

Fadiş romanını başarılı kılan özelliklerden biri de dil ve üslubudur. 12-15 yaş aralığındaki çocuk dünyasını yansıtan ve onların seviyesini aşmayan kelimeler, büyük bir titizlikle seçilmiştir. Bu titizlik, küçük okurların kelime hazinesini zenginleştirmede de işlev üstlenmiştir. Özellikle deyimler açısından zengin bir içeriğe sahip olan roman, anadilinin sevdirilmesi ve doğru kullanılması noktasında dikkat çeker.

\section{Kaynakça}

Anameriç, H. ve Rukancı, F. (2015). Türkiye'de ve Türki cumhuriyetlerde çocuk edebiyatının tanıtımında filatelik materyallerin önemi. Edebiyat Fakültesi Dergisi, 32(2), 25-47.

Aslan, C. (2008). Ayla Çınaroğlu'nun "Mago" adlı kitabının yazınsallık ve çocuğa görelik açısından incelenmesi, A. Gültekin, M. Semerci, F. Koşmak (Haz.). Çocuk ve Gençlik Edebiyatında Ayla Çınaroğlu Sempozyumu, 17-19 Ekim, Eskişehir, Bildiriler içinde (s. 35-48). İstanbul: Uçanbalık Yayınları.

Bilkan, A. F. (2005). Çocuk edebiyatı: kavram ve mahiyet. Hece Dergisi Çocuk Edebiyatı Özel Sayısı, 104-105: 7-17.

Dayığlu, G. (2005). Fadiş. İstanbul: Altın Kitaplar Yayınevi.

Enginün, İ. (1991). Yeni Türk edebiyatı araştırmaları. İstanbul: Dergâh Yayınları.

Kerman, Z. (1998). Yeni Türk edebiyatı incelemeleri. Ankara: Akçă̆ Yayınları.

Köktürk, Ş. (2005). Çocuklara şiirin, felsefenin ve imgesel dünyanın kapılarını açan tür bilmeceler. Hece Dergisi Çocuk Edebiyatı Özel Sayısı, 104-105: 120-127. 
Meriç, C. (1986). Kültürden irfana. İstanbul: İnsan Yayınları.

Sağlık, Ş. (2005). Çocuk romanları. Hece Dergisi Çocuk Edebiyatı Özel Sayısı, 104-105: 234-255.

Sever, S. (2013). Çocuk edebiyatı ve okuma kültürü. İzmir: Tudem.

Sınar Çılgın, A. (2007). Çocuk edebiyatı, İstanbul: Morpa Kültür Yayınları.

Sivri, M. (2014). Kitaplarımda umuda çok önem veririm. M.R. Şirin (Ed.), Türk Dili Çocuk ve Illk Gençlik Edebiyatı Özel Sayısı C. CVII S. 756, içinde (ss. 552-560). Ankara: Türk Dil Kurumu Yayınları.

Şimşek, T. (2006). Çocuk edebiyatı. T. S. Halman (Ed.), Türk edebiyatı tarihi C. 4 içinde (ss. 543-564). İstanbul: TC Kültür ve Turizm Bakanlığı Yayınları.

Şirin, M. R. (1994), 99 soruda çocuk edebiyatı. İstanbul: Çocuk Vakfi Yayınları.

Tökel, D. A. (2005). Eskilerde çocuk eğitimi: çocuk edebiyatı gözüyle eskiye bakmak”, Hece Dergisi Çocuk Edebiyatı Özel Sayısı, 104-105, 76-88.

Yalçın, A., Aytaş, G. (2008). Çocuk edebiyatı. Ankara: Akçağ Yayınları. 